PAIGE WEST

\title{
Translation, Value, and Space: Theorizing an Ethnographic and Engaged Environmental Anthropology
}

\begin{abstract}
In this article, I argue for placing the politics of translation and theories of value and spatial production at the center of environmental anthropology. For the past ten years, the Gimi-speaking peoples living in Maimafu village, Papua New Guinea, have taken part in an integrated conservation and development project attempting to foster a local system of valuing "nature" by tying biological diversity to economic markets through the creation of "eco-enterprises." However, the project fails to consider how Gimi produce, theorize, transmit, and express knowledge. Using ethnographic material concerned with hunting and song composition, I show that Gimi understand their forests to be part of a series of transactive dialectical relationships that work to produce identity and space. I also demonstrate that, as part of this project, Gimi social relations with their forests have been translated in ways that fit their beliefs into generic and easily understandable categories. This has been detrimental to the conservation project and it is politically problematic for an engaged environmental anthropology. [Keywords: personhood, neoliberalism, conservation, environment, Papua New Guinea]
\end{abstract}

I

$\mathrm{N}$ THIS ARTICLE, I address the issues of translation, value, and spatial production, three topics that should be at the heart of an engaged, ethnographic, and theoretically informed environmental anthropology. To discuss these topics, I present an ethnographic case study of Gimi-speaking peoples in the Eastern Highlands Province of Papua New Guinea (PNG) who are involved in an Integrated Conservation and Development Project (ICAD or ICDP). In particular, I examine Gimi practices of hunting and composing songs about tree kangaroos (Marsupialia: Macropodidae, Dendrolagus), arboreal marsupials that are found only in New Guinea and northeastern Australia.

For the past eight years, I have conducted research among Gimi peoples and their interlocutors: conservation practitioners, missionaries, U.S. Peace Corps volunteers, gold miners, and tourists (West 2000, 2001, in press). As an environmental anthropologist, I am often asked to translate (Zerner 2003) and make legible (Scott 1998) the actions and beliefs of one set of actors for another. In terms of explaining actions, Gimi wish that I could make the seemingly bizarre behaviors of tourists make sense, biologists ask me to explain Gimi forest-related practices, and gold miners ask me to clarify biologist's behaviors. In terms of explaining beliefs, tourists wish to know if Gimi have "magical" ways of relating to forests, biologists want to know if Gimi "value" plants and animals, and Gimi want to know why outsiders are interested in their land.

Acts of translation-made by translation professionals such as anthropologists, lawyers, and sociologistssometimes fail to show that environments are both materially and symbolically created (Zerner 2003:2-6). Instead they focus on environments as knowledges that can be used and resources that can be acted on (Ellis and West 2004). These acts of translation are deeply political because they connect volatile claims about environments to claims about identity and rights (Zerner 2003:2). Anthropologists have argued that environmental knowledges are valuable for conservation and development (see Posey 1998; Sillitoe 1998a, 1998b) and some conservation scientists have concurred (Dumbacher et al. 1992; Gadgil 1993). Although local knowledge may be "incompatible" with scientific knowledge (Berlin 1992), many environmental anthropologists attempt to make conservationists understand and value local knowledge by translating it into categories that scientists can easily understand and assimilate into their epistemologies. They do this because scientists who do not see the value of local knowledge are much more likely to suggest conservation polices that are not socially equitable

AmERICAN ANTHROPologIST, Vol. 107, Issue 4, pp. 632-642, ISSN 0002-7294, electronic ISSN 1548-1433. (C) 2005 by the American Anthropological Association. All rights reserved. Please direct all requests for permission to photocopy or reproduce article content through the University of California Press's Rights and Permissions website, at http://www.ucpress.edu/journals/rights.htm. 
(Harper 2002). But environmental translations that portray people as rational, neutral, and economically minded, and their socioecological actions as resource use (see Paulson et al. 2003), often miss the fact that human relations with the natural world are aesthetic, poetic, social, and moral. In addition, for many, all scales of socioecological actions (acts of great spiritual importance, mundane day-to-day acts, and acts related to outside pressures) can be seen as making claims on (Zerner 2003:60) and affecting environments (Vayda 1996).

Frederick Errington and Deborah Gewertz (2001) argue that as local knowledge is made understandable to outsiders through translation, local people lose control over culturally specific vernacular knowledge. Furthermore, when local knowledge and local social life are rendered legible, a "generification of culture" takes place. The complex and special character of knowledge and of the social practices it engenders are shaped to fit already existing categories of "otherness," thus softening the edges of difference so that it can be controlled and consumed by powerful outsiders (Errington and Gewertz 2001). On-the-ground knowledge and practice begin to look like the outside renderings of them, thus erasing the vernacular and creating a situation in which local social structures begin to conform to imposed models and ideologies (Carrier and Miller 1998; see West and Carrier 2004). This has material consequences for people and their environments.

Political ecologists, who wish to explain social and ecological issues and assume that local socioecological actions and events are always derivative of extralocal economic and political structures (Vayda and Walters 1999), tend to translate socioecological agency in ways that generify it (Errington and Gewertz 2001). A political ecology "actor-centered" approach, although well intentioned, suggests a view of socioecological relations in which people act on biological diversity, as opposed to interacting with plants and animals, and on each other, as opposed to acting with each other in dialectical productive relationships. In turn, people are acted on by the environment and extralocal structures (Paulson et al. 2003). This approach reduces local socioecological lives and does not leave room for complex understandings of the dialectical creation of "self" and "other," central concepts to ethnographic understandings of the relations between people and environments. My argument is that environmental anthropologists need to carefully consider how we allow fundamentally Western concepts and modes of explanation to dominate practices of translation. I am not simply arguing for a return to the universal versus relativist debate, because I am not claiming that Gimi ways of being are not translatable. Rather, I am saying that translations need to take into account indigenous understandings of knowledge and practice-asking questions about how knowledge is produced, theorized, transmitted, and encoded (Gegeo and Watson-Gegeo 2001) and about indigenous explanations (Walsh 2004).

Actions and beliefs with regard to biological diversity can be seen as what David Harvey (1989), Henri Lefebvre
(1991), and Neil Smith (1990, 1996), among others, have referred to as "the production of space." Lefebvre argues that space is not a given static field in which human relationships and actions take place but, rather, that it is always produced by social relations, actions, ideas, and imaginaries (Lefebvre 1991:26). There are products in space, like Crater Mountain, which have a particular history of production as "place," and there is the process by which space is produced or generated (Lefebvre 1991:37). ${ }^{1}$ In this formulation, space is made up of physical or material space, mental space, and social space with each kind of space underpinning and presupposing the others (Lefebvre 1991:14). Lefebvre proposed a triad of dialectically related categories for spatial production: (1) spatial practice, the practices and actions of a society that "secrete" the society's space (Lefebvre 1991:38); (2) representations of space, how a society "conceptualizes" space through science, planning, technology, and its other knowledge-producing social forms (Lefebvre 1991:38-39); and (3) representational spaces, "space as directly lived through its associated images and symbols" (Lefebvre 1991:38).

The human side of the production of space is well theorized (Harvey 1989; Lefebvre 1991; Smith 1990, 1996). However, Gimi understandings of "personhood" are attained through transactive relationships between people and mutual recognition between themselves and animals, as well as through a view of forests as being produced through exchanges between people, ancestors, and animals. By allowing theories of spatial production to include nonhuman actions, Gimi understandings of "personhood" expand the theories of spatial production that I discuss above. Gimi spatial practices have to do with animals: Animals as active beings populate their representations of space, and their representational spaces are full of animals as symbols. It is not simply that personhood, other, and environment get formed along with spatiotemporal relations (Harvey 1996:264), although this is, indeed, the case. Rather, Gimias-being being-in-the-world is dialectically connected to animal-as-being being-in-the-world (see Ingold 2000), and it is through this mutual recognition that the Gimi socioecological world is created.

When Gimi conceptualize and use biological diversity for their subsistence and ritual needs, they are taking part in dialectical transactive relationships that produce them as persons, animals as active agents, and forests as living social arenas. These relationships are entered into on three levels_-among people, between people and ancestors, and between people and animals-and these relationships create Gimi subjectivity and produce Gimi forests. The generative relations that produce Gimi and space take place on five levels: through (1) the movements of auna (life forces) and kore (spirits); (2) the hunting of and consumption of animals; (3) actions that make forests into property; (4) social relations between people, spirits, and animals; and (5) reproductive labor. Through their understanding that Gimi value forests as potential commodities and their portrayal of Gimi as threats to their forests, conservationists worked to 
generify culture. Consequently, an engaged environmental anthropology that wishes to productively critique current conservation practice and contribute to socially equitable conservation in the future must take issues of translation, value, and space as starting points for analysis. I will return to this issue in the conclusion.

\section{THE MAIMAFU GIMI}

Maimafu is a series of 15 ridge-top settlements $(1,500-1,700$ meters [4,921-5577 feet]) with approximately 700 people in the shadow of Crater Mountain, an extinct volcano that last erupted in the Pleistocene. Maimafu's residents are shifting horticulturists who rely on coffee production for their cash needs and who hold the forest surrounding their settlements in traditional tenure. In the 1970s, Seventh Day Adventist missionaries began working in the area. Since 1992, the year that the Adventist-funded village airstrip was completed, there have been no pigs in Maimafu. When the airstrip was completed, people voted to kill off their pigs because pigs are thought to damage airstrips with their rooting. In much of PNG, pigs are a part of a socioecological complex that includes subsistence, religion, exchange, and ecology (Rappaport 1984). In Maimafu, because there are no pigs and no trade stores-and, hence, no opportunity to buy tinned fish or imported mutton-protein needs are instead met with locally hunted game and village-raised chickens.

Adventists are supposed to follow dietary restrictions. In Maimafu, the consumption of pigs, some pouched animals, rats, amphibians, and eels are prohibited. The level of a follower's adherence to this list is contingent on social factors that pertain to gender and education levels. For the most part, in Maimafu village, people do not consume pork at all. When hunting deep in the forest, if people encounter a pig, they will kill it and eat it. When people go to other villages where pigs are kept, many will consume pork. Men are more likely to consume pork even if they are devout Adventists. In addition, people who have not attended mission schools are more likely to consume it. The other restrictions are followed much more loosely and are contingent on personal preferences, availability of protein from other sources, and people's distance from the village when they come across an animal. The vast majority of people in Maimafu consume hunted animals. ${ }^{2}$

Even with their conversions to Christianity, older Gimi still hold onto old ideas about forests, their symbolism, their inhabitants, and their roles in Gimi social lives. This is not to say that people have resisted Christianity (Comaroff and Comaroff 1991), just that it has not become the center of social life as it has in other parts of PNG (Robbins 2004). The main changes associated with conversion are changes in rituals associated with initiation, changes in the structure of the workweek, and the beginnings of a loss of knowledge about mythology. In some places in Melanesia, conversions lead to a noticeable shift in ideas about "personhood" in which self comes to be situated at the center of the social (Errington and Gewertz 1995:116; see White 1991). Although I have only worked with Gimi for eight years, earlier ethnographers produced a large body of literature concerned with Gimi sociality (see Gillison 1977, 1980, 1983a, 1983b, 1987, 1991, 1993, 1994; Glick 1963, $1964,1967,1972)$, which, combined with my own research, does not support the idea that a similar process has taken place among the Gimi. Throughout my fieldwork, I have been continually struck by the persistence of meanings regarding forests, ancestor spirits, animals, movements of the dead, and ideas about persons as made through exchange, as Leonard Glick and Gillian Gillison described them. The people targeted by the ICDP are adults who undertake the ecological actions that conservation wishes to curtail. These adults, although attending church regularly, maintain the cosmological beliefs that I describe below.

\section{CONSERVATION ON GIMI LANDS}

Since 1994, Gimi have taken part in an ICDP that encompasses their land, labor, and lives. ${ }^{3}$ The spatial and social manifestation of this project is the Crater Mountain Wildlife Management Area (CMWMA), a 2,700-squarekilometer area (about 1,043 square miles) that is home to two ethnolinguistic groups and numerous species of plants and animals (Mack and Wright 1996; Wright n.d.; Wright et al. 1997). The ICDP was initially based on the idea that Gimi would begin to "value" and then work to "protect" biological diversity if their economic livelihood was directly connected to it. The Biodiversity Conservation Network (BCN) - a component of the Biodiversity Support Program (BSP), a short-term program that was funded by USAID and the World Wildlife Fund (WWF) - funded and helped to design the ICDP at Crater Mountain. According to the architects of the $\mathrm{BCN}$, it was conceptualized to determine, using scientific principles, the conditions that make for effective conservation (Salafsky and Wollenberg 2000; Salafsky et al. 2001:1586). The driving ideology behind the BCN was one of economic valuation:

\begin{abstract}
Biodiversity represents the very foundation of human existence. Yet by our heedless actions we are eroding this biological capital at an alarming rate.... Beside the profound ethical and aesthetic implications, it is clear that the loss of biodiversity has serious economic and social costs. The genes, species, ecosystems and human knowledge which are being lost represent a living library of options available for adapting to local and global change. Biodiversity is part of our daily lives and livelihood and constitutes the resources upon which families, communities, nations and future generations depend. [BSP 1996:iv]
\end{abstract}

BCN funded 39 projects worldwide, all of which included the creation of "ecological enterprises" like ecotourism lodges, nontimber forest product extraction, smallscale timber harvesting, or bioprospecting (Salafsky et al. 2001:1586). BCN was a part of a neoliberal shift in conservation. It was designed to use products and production to integrate rural places into world markets (Schroeder 1995:326). 
This sort of conservation favors trade liberalization, export economies, privatization, and bypassing the state (Hartwick and Peet 2003:189). In this framework, development became the ability to participate in worldwide markets (Edelman and Haugerud 2005:16) and conservation was inextricably tied to development (Sachs 1993). The market is seen as both the savior of biological diversity and the most rational and efficient way to organize social and economic life. The seemingly "impassable divide" between growth and conservation is imagined to be bridged by marketoriented sustainable development (Hartwick and Peet 2003:189).

Each project funded by the BCN was defined using the spatial metaphor of "site," and all the people involved in the projects-local landowners, biologists, U.S. Peace Corps volunteers, and others-were termed "stakeholders." The "sites," "stakeholders," and "ecological enterprises" were given a temporal dimension in that they were funded and assessed over a period of four years (Salafsky et al. 2001:1587). As part of its "scientific" approach, BCN devised a "core hypothesis" postulating that "if local communities receive sufficient benefits from an enterprise that depends on biodiversity, then they will act to counter internal and external threats to that biodiversity" (BSP 1996:1). BCN also developed a set of "monitoring tools" to be used to test the hypothesis, an "index of threat-reduction assessment" to assess "the percentage of identified threats at each project site addressed over the life of the project," and a series of "models" to direct and assess all projects (Salafsky et al. 2001:1587). The BCN staff, like many ecologists and economists, took as their starting point the assumption that the environment is simply livelihood for rural peoples (Tsing 2003:24). Given this assumption, they thought the most rational way to convince local communities to conserve was to link their forests to market-based enterprises. In Maimafu, these enterprises were handicraft production, ecotourism, and the training of local people to work for scientific researchers as paid employees.

Inherent in the original design of the CMWMA, and directly connected to the $\mathrm{BCN}$ view of environment as biological capital and people as economic actors, was the idea that Gimi are a threat to their forests (West 2001). They are portrayed as such in publications (Johnson 1997:396), proposals (Research and Conservation Foundation of Papua New Guinea-Wildlife Conservation Society [RCF-WCS] 1995), and in interviews (West 2001, in press). Gimi are thought to threaten their forests through their land-use practices of gardening, cutting trees for fuel and constructing houses; their hunting practices; and through the pressure put on their forests because of their increasing population. Portrayals of Gimi use of the forests also imply that Gimi value them because of the money to be made off the "natural resources" within. Assuming as much, conservation practitioners, hence, created local ecological enterprises, turning bits of biological diversity into commodities that could be used to "increase the average annual per capita income of clans" (Johnson 1997:397). In doing so, they demonstrated that they did not understand that Gimi relations with their forests are social in nature.

\section{MAKING GIMI, MAKING FORESTS}

For Gimi, everything is a "gift" from the forest as it is the physical incarnation of their ancestors' life force (Gillison 1980, 1993). People and forests will always be-and have always been-in a constant transactive relationship, making and remaking each other over time. Gimi believe that people are made up of flesh, which is made by their social relations and transactions with the living, and auna, which is made by their social relations and transactions with the dead. Auna can be translated as "soul," "power," "vital spirit," "familiar spirit," and "life-force" (see Gillison 1993:365 and Glick 1963:201). Auna is the

invisible animating aspect of a person, ghost (kore), an-
imal, or plant manifested in breath, voice, pulse, heart
beat, etc., and in the capacity for growth, and present in
all body exuviae (urine, feces, sweat, tears, hair, blood,
etc.) and discarded scraps of food or tobacco. [Gillison
1993:365]

When people die, their auna leave their bodies and their hamlets, but this can take several days and during this time the auna can be quite dangerous because it can cause sickness and even death of the living (Gillison 1993:122). ${ }^{4}$ When a man's auna leaves his body for good, it migrates to his clan's ancestral hunting grounds. If a woman dies when she is unmarried, her auna goes to her father's clan's grounds; if she is married, it goes to that of her husband. ${ }^{5}$ Once there, the auna slowly turns into kore ("ghost," "spirit," "ancestor," and "wild") and lodges in plants, animals, streams, mountains, birds, and other bits of the forest (Gillison 1993:122). Women and their spirits are cold, low, and close to the ground and they infuse the things that slither and move along the forest floors. Men and their spirits are lofty and high so they soar through the forests as birds and as wind. But as auna dissipates, it lodges everywhere. The life force of a person becomes the forest, with the "wild" parts of the forest becoming filled with and "animated by" the kore of deceased Gimi (Gillison 1993:199). In the past, when a man died, his relatives took his bones to his ancestor's lands so that they could "enrich his clan forest, giving rise to new life forms in the way semen engenders life in a woman's body" (Gillison 1993:101).

Gimi also believe that auna can leave the live body of a sleeping person and fly through the forests and village at night. At times, this life force can lodge itself in the bodies of birds, tree kangaroos, possums, and other animals (Gillison 1993:108). These nighttime adventures of the auna manifest as dreams and they are intimately tied to Gimi ideas about conception. When a woman first comes to her husband, she still has her father's clan's life force inside of her. During her waking hours, she is forced to drink water from rivers that flow on her husband's land so that his ancestors can drive out her father's clan's life force (Gillison 1980:163). Thereafter, as she dreams, her auna leaves her body and goes to her husband's clan's forests. In these 
nighttime journeys, the animals in which the woman's auna chooses to lodge itself reveal the gender of the child she will have: If she dreams about a frog, fish, or grounddwelling animal, she will conceive and bear a female child; if she dreams about birds, she will conceive and bear a male. The animal in the dream is "the ancestral incarnation of the fetus" (Gillison 1993:208).

In death, the auna of a person becomes kore and then returns to the forests from which it came. The auna was merely the form that kore took while the person was living, but it always was, and always will be, the kore that animates the forests. It is that same kore that merges with a woman's auna when it travels at night to her husband's clan's forests, allowing her to conceive his child (Gillison 1980:160).

The human life force, forests, and animals are intimately tied. When a person dies, his or her auna "clings to its body" and must be helped along toward the forests (Gillison 1993:122). People must sing to a corpse, sit with it, and wail in their sorrow so that it does not cling to the body or hamlet forever. But slowly, "over time, auna penetrates the deep forests and is gradually transformed entirely into kore, taking up residence in giant trees, high mountain caves, and every kind of wildlife" (Gillison 1993:122). Once the auna goes to the forests and begins to infuse itself into wildlife, it becomes part of not only the forest but also the never-ending cycle of Gimi mythology. When the auna "penetrates" marsupials, animals that it seeks out in particular, it reenacts events from traditional women's mythology and comes to be part of this mythic cycle (Gillison 1993:9295, 122). Marsupials can also be used in divination rituals: After a person's wandering kore has been "housed" (Gillison 1993:122) in an animal, it can help living relatives find his or her killer through divination rituals involving the live animal being questioned by elder men. So marsupials are not simply animals to Gimi, they are the literal embodiment of ancestors; what has been translated as "environment" is not simply a place filled with floral and faunal resources waiting to be used or made into commodities, it is a place of social relations between the living and the dead. ${ }^{6}$

\section{GIMI SONGS}

Worldwide, people living in biologically diverse places tell stories, sing songs, and recite poems that are intimately connected to the politics of nature (Zerner 2003). People also have rich ethnozoologies (Berlin 1992; Bulmer and Menzies 1972; Rea 1998). In his discussion of songs in PNG, Steven Feld (1996) articulates how the Kaluli come to sense, know, and create "place." He discusses their acoustic sensations, knowledges, and imaginations and argues that "as place is sensed, senses are placed; as places make sense, senses make place" (Feld 1996:91). James Weiner shows that, in PNG, movements across the landscape associated with hunting are memorialized in song and that these songs work to create men and forests (1991:110). Paul Sillitoe (2003) shows how hunting incantations in PNG work to create place and animals. I want to expand this notion that people create place through song by arguing that Gimi create self and animal through song and hunting, and that the these practices are part of Gimi spatial production.

Gimi hunt marsupials both purposefully and opportunistically, yet highly prized marsupials live at high altitudes and are difficult to find without well-trained hunting dogs. In the past, much marsupial meat was taboo. However, during the drier parts of the year, men went in clanbased hunting parties to the high forests to kill large numbers of marsupials for rituals, and marsupial meat was the only meat consumed during these important social events (Gillison 1993:38). Today, people spend much of their labor time and energy during the dry season harvesting coffee. This has shifted the practice of hunting parties to the wetter season. Because they no longer associate marsupial consumption with rites and rituals exclusively, when animals are encountered during trips to gardens or trips to the forests for other purposes, people are likely to kill them. Marsupials often killed in this manner are Ground Cuscus or hama (Phalanger gymnotis), Northern Common Cuscus or jabe (Phalanger orientalis), Common Spotted Cuscus or ota (Spilocuscus maculates), and several species of Echymipera and Bandicoot or hau. Even with the local availability of these species and the modern lack of association of marsupials and sacred ritual, men still make special trips to high forests to hunt tree kangaroos because they are highly prized as meat and because the animals are rarely found close to human settlements.

Gimi narratives about marsupials are found in theatric performances, creation myths, divination and initiation rituals, and songs. Theater was still frequently performed in some Gimi areas (Gillison 1993:72-75) until the 1980s, when there was a push by missions to do away with "pagan" rituals; it is now very rare. Since the mid-1970s, when Adventist missionaries began activities in and around Maimafu, the Maimafu Gimi have not performed the ritual enactment associated with male initiation. However, Gimi also describe the behaviors of marsupials when discussing divination rituals associated with sorcery, which is on the rise in the area. ${ }^{7}$ Additionally, people describe marsupials and their behaviors in songs. Many of the marsupial songs are composed by individuals and then perhaps become known by others (Gillison 1993:262). Many songs recount a certain historic event on the composer's land and are concerned with property rights, animal behavior, and the social relations between humans and animals.

The following song about kile (Macropodidae Dendrolagus goodfellowi) celebrates the animal's resolve, when shot by an arrow, to go as high as possible in a tree:

Gomo kile kola kola amene abo

lepetepe me hulu $o$.

Gamogo asitai hulu siba kereamune

lepetepe me hulu o.

Gomo kile kola kola amene abo

lepetepe me hulu o.

The kile (that I see with my own eyes) is bleeding, is bleeding, his blood runs down, it runs down, but he goes up the tree. 
He wants to go up to the gamogo leaf (that I see with my own eyes), his blood runs down, it runs down, but he goes up the tree.

The kile (that I see with my own eyes) is bleeding, is bleeding, his blood runs down, it runs down, but he goes up the tree. [conversation with author, July 10, 2003]

The translation makes clear that it is a song sung about a specific kile, the phrase amene abo indicates that the singer has seen this kile with his "own eyes." It is not a kile that lives in collective memory, but, rather, a kile that is in a specific tree, at a specific place, at a specific time. This is important because it indicates that this song is not simply "indigenous knowledge" that can be recorded and passed on. Neither is it part of what Anna Tsing (2003:27) calls "dematerialized aestheticism" - viewing forest peoples' knowledge and poetics as spiritual and holistic and contrasting them to those of modern or Western peoples. The kile in the song sees the composer, and the composer sees the kile. It is in that moment of recognition that hunter and hunted form a social relationship of exchange. The kile as food makes the hunter's body, whereas the kile as embodied ancestor or kore makes the auna of the hunter. This moment constitutes Gimi, other, past, present, and future and reveals Gimi as being-in-the-world in ways that are absolutely not about economic valuation of "natural resources."

Regarding animal behavior, spatial production, and relations to clan ancestors and the past, the composer of the song says,

When you shoot kile or kama (Macropodidae Dendrolagus dorianus) with an arrow, the first thing that happens is that blood comes down from its nose. That is when you know that you have gotten it. When it begins to bleed, and it knows that you've gotten it, it always goes higher and higher and higher in the trees. It knows and it goes. It knows and it goes. Kile and kama always go to the same tree when they are shot, they try to find the gamogo [a kind of tree]. So you know when you shoot one and you lose it, it has gone to the gamogo.

Usually, when you see them, or when the dogs find them, they are ya-ahmipi (sitting at the base of a tree) or milivi (down in a low place where they can find food). They sleep ya-ahmipi and they find most of their food milivi. At night they get cold sleeping ya-ahmipi, so when they wake up in the morning, they go yahalagapi (to the top of the trees). They stay there and warm themselves in the warm sun all morning. At folaelae (midday) they come down to eat and they find their food. If the female has a baby it is easy to catch her, she is thinking about her baby and not about other things. The baby is in her ahme $k o$ (pouch; lit., breast + net string bag) and she is slower than usual. They are always together, bana and badaha (male and female), they are like people and they get married. ... When my ancestor, Lioni, came to this place [in the song] first, he was the first one, he killed kile and the blood from his nose dripped on this ground. Since then, this has been Lionisuwana (my family's ground). [conversation with author, July 10, 2003]

The first part of this explanation is about the mutual recognition between hunter and animal. The animal and the hunter know each other's behaviors because they have both done this before. The hunter has done it during his life and during his ancestor's lives, and the animal knows the behaviors because it is the physical embodiment of the kore of the hunter's ancestors. The second part of the explanation is about producing forests as spaces of animal and human action. The composer discusses the animal's behavior in detail so as to show that there is a way-of-life of the creature, it is not simply an animal that acts randomly but a being that has customs. As such, the animal is much more than a "resource," it is a being that has social relations with other beings and a set of temporally guided behaviors. The final part of the narrative shows how clan grounds are claimed and how these claims are reasserted through the actions of hunters and animals. People claim ground through usecurrent, historic, and mythic. The hunting and killing of kama and kile is often recounted when one asks a man why his clan holds a particular piece of ground. The composer explained to me,

We know that the ground is Lionisuwana because my ancestor killed kile here. He could have only killed kile with the help of his ancestors. They showed him the way to this place for the first time. They led him to this part of the forests because they were already here. [conversation with author, July 10, 2003]

Songs can also be more specifically concerned with moving the dead into the forests:
I want to see the Yauw-one waterfall
kama and waya [Papuan Lorikeet Charmosyna papou] we see you go up the waterfall
I want to see the Tiruwa-one waterfall
kile and hane [Little Red Lorikeet Charmosyna pulchella] we see you go up the waterfall.
[conversation with author, October 14, 2004]

This song's composer, Kano, explained that when he sings it, he thinks of his daughter who died while she was walking in the forest when a tree toppled over and crushed her. Kano knows that sorcery was responsible for her death, because she was walking on his clan's ancestral land and because the tree was one that he was going to use to build her brother a new house-the very tree Kano had picked because it was close to where his own father had once killed kile. The land is very close to their hamlet so Kano was certain that his father's luck in finding kile there had to do with the kore of his ancestors. Logically, for Kano, a place like this could not cause his daughter's death through ordinary means. His daughter's death by sorcery is a constant source of pain for Kano and the song helps to lessen his pain, it is about healing the living and helping the dead. After I recorded the song, Kano explained to me,

When I sing this song it brings back the pain of her death. It takes me there to the place where she died. I sing about the Yauw-one and Tiruwa-one (the waterfalls) because if I could drink from the water on my ground, I could begin to lose my sorrow. I composed the song right after she died. I went to the place and I sang to lose my sorrow. [conversation with author, October 14, 2004] 
Gillison, writing about the actions taken after a death to ensure that the auna leaves the person's hamlet, says, "Waterfalls are called kore abe or 'ghost urine,' a euphemism for semen, because, like mountains, giant trees and other forest monuments, they represent ultimate transformations of personal auna into kore" (Gillison 1993:122). Kano's song is a mourning song that worked to draw his daughter's auna into the forest.

Songs about marsupials are very salient in terms of birth, life, death, and afterlife. For older Gimi, "hunting marsupials" is a metaphor for conceiving a child (Gillison 1993:211). In the past, if a man's wife had a baby, he would venture to the forests and kill many marsupials guided in his hunting by his own dead parents (Gillison 1993:236). ${ }^{8}$ Marsupial meat was also intimately tied to Gimi systems of head payments, rites, and relationships between family members that contribute to the growth of a child through exchange relations. These relationships tie a man's clan and his wife's father's clan tightly together, thus reproducing the social relations between them. Kano's song encodes the relationship between children, life, and parents onto the forests and the tree kangaroos. These songs show that Gimi see themselves as having social relations with animals in similar ways to their social relationships with people, relations of exchange and transaction. They also show that Gimi produce their forests as meaningful spaces through exchanges and transactions with animals, people, and spirits. In what follows, I will show that because Gimi come into being as persons through transactions and because space comes into being for Gimi through transactions, there is a link between the production of personhood and the production of space.

\section{DIALECTICS OF PERSONHOOD AND SPACE}

The Gimi world is produced through social relationships between beings. These beings are people, ancestors, spirits, and animals. These social relations are not neutral and economic; they are familial and poetic. In societies based on gift exchange, like Gimi society, identity and personhood are made through social relationships with others. People's capacities are seen as they relate to others and their identities are understood as comprised of the sources that went into making them (Strathern 1988:131). Personhood is located at the confluence of relationships that encompass certain knowledges, social capacities, and practices that can only be expressed and utilized with reference to others. Because people are constantly entering into new social relationships, they are always making and remaking identity because that identity - the idea of who they are at any given time-is only realized through their relations and transactions with others (Strathern 1988:128). For Gimi, these generative transactions include transactions with nonhuman animals.

In a recent article concerned with anthropological practices of explanation, Joel Robbins argues that political anthropology is less than adequate because it has never had "its own equivalent of the formalist/substantivist debate" (2003:9). Anthropologists in this subfield have never con- fronted or come to terms with their "fundamental Western assumptions" or the competing fundamental assumptions of their subjects (Robbins 2003:9). The philosophical underpinnings of the subfield view people as individualistic and interested in material gain and self-protection (Robbins 2003:10). Concomitant with this view is the idea that social relationships are always potentially threatening: They invite domination, inequality, and loss of property while also exposing people to hegemony and forcing them to practice resistance (Robbins 2003:10). Drawing on his work with Urapmin peoples in PNG, Robbins's corrective to this model of social relationships is to propose a Hegelian model in which struggles, political and otherwise, work to form social relationships and not limit them.

In Robbins's reading of Hegel, mutual recognition creates subjects and works to form the "substance of society" (Robbins 2003:10), thereby creating people who seek relationships and recognition and not ones who work to maintain an isolated self. Urapmin seek relationships and recognition everywhere-with each other, with the mining company working on their lands, and with the nature spirits that currently enliven and originally produced their forests. As relationship seekers, the Urapmin produce a certain kind of "politics of nature" based on their understanding of personal property (Robbins 2003:11). Urapmin make their forest world and themselves through the social relations that revolve around property and ownership. These social relationships can be between Urapmin, between Urapmin and the nature spirits who own the features of their landscape, and between Urapmin and outsiders. Robbins formulates Urapmin in their own terms, not in the terms usually encouraged by political anthropology, thus finding a new way to translate Urapmin politics for his readers.

When Gimi think about and interact with the forests, there is a constant dialectical relation between organism and environment (Ingold 2000) that is directly connected to how Gimi make themselves and others through transactive relationships (Strathern 1988) and through the sort of "mutual recognition" that creates subjectivity (Robbins 2003:10). This mutual recognition takes place on three levels: (1) between individuals, (2) between people and their ancestors, and ( 3 ) between people and animals. Tim Ingold (2000) develops the idea of "organism-in-its-environment" and contrasts it against the more traditional idea of organisms in an environment. For Ingold, the environment is only in relation to the organism, and the organism is only in relation to the environment (Ingold 2000:172). I want to push Ingold's argument to include the kind of mutual recognition that Robbins reads in Hegel and that is shown in the case of the Urapmin (Robbins 2003); for example, with no Gimi there is no tree kangaroo and with no tree kangaroo there is no Gimi. Ancestral spirits enliven Gimi forests, but it is, in part, the mutual recognition between Gimi hunters and hunted animals that creates subjects, produces space, and lies at the heart of Gimi politics of environment.

This transactional being-in-the-world, in which subjectivity is constantly being produced, is the way that Gimi 
see "self" and "other"-be that other another person, an ancestor's spirit, or a tree kangaroo. Gimi are in existence in relation to their forests and their forests are in existence in relation to Gimi; there is no Gimi without forest and no forest without Gimi. This being-in-the-world as a generative transactional relationship takes place on five levels for Gimi: through (1) the movements and transactions of their auna (life force) and kore (spirit) during conception, in dreams, and after death; (2) the hunting and eating of animals; (3) the meaningful human action that transforms forests into clan property; (4) relations between humans, animals, and spirits that literally created the Gimi universe and that are retold through a concert of male and female myths; and (5) reproductive labor. By viewing Gimi as a threat to their forests on the basis of an assumption that Gimi value them only as natural resources and potential commodities, conservation, indeed, "got it wrong." Further, by using similar categories to translate social life among Gimi to conservation-related actors, environmental anthropology would generify culture, failing to explain that Gimi cosmology creates a conceptual divide that makes the establishment of "values" impossible.

\section{CONCLUSION}

I conclude this article with a brief discussion of how the focus on translation, value, and space might play out in both anthropology and in the spheres that environmental anthropologists wish to influence. Gimi understand their forests to be a source of personhood, society, and sustenance, in which the spirits of ancestors infuse life into rivers, trees, birds, marsupials, and humans (Gillison 1980:143). I argue that the translations of these socioecological understandings, and the subsequent actions of the $\mathrm{BCN}$, are neither accurate nor particularly productive if the goal is to "conserve" forests held by Gimi. Such translations define Gimi as rational economic actors who value forests because of their potential as commodities and status as resources. This misunderstanding forms the basis for the interventions-specifically ecotourism, handicraft production, and attempts to regulate hunting practicesassociated with the Crater Mountain ICAD project, which has neither brought money to Gimi nor curtailed the practices termed as "threats" (see West 2000, 2001, in press; West and Carrier 2004). In this article, I explore a more nuanced translation: In opposition to ecological and economic ways of knowing the environment in which humans are seen as a threat to nature, Gimi ways of knowing view humans as generative of and generated by social relations with what the Western world (but not the Gimi) categorizes as "nature." 9

The BCN wanted "stakeholders," "sites," and "ecoenterprises" - categories into which Gimi were translated. Afterward, the categories were monitored to measure their integration into global markets for ecoproducts. Over the course of four years, these categories were to be integrated in a way that encouraged development and contributed to conservation. The initial use of these categories called for a generification of culture - a translation of local social life that split Gimi being-in-the-world into "people," "plants and animals," and "environment." Part of this generification or production of ordered and easily consumable difference, with regard to conservation in PNG, is directly connected to the BCN's neoliberal approach to conservation. The categories used by the BCN also produce a particular kind of space and a certain kind of person who is located in place, and encode an economic rational view of people's relations with their environment. Gimi ways of making "self" and "other" and of being-in-the-world produce a fundamentally different space.

With regard to translation practices generally, I am not arguing that anthropologists and others should not seek to understand lifeways different from their own. Instead, I assert that environmental translations should not take for granted that people everywhere approach biological diversity as if it were composed of potentially commodified matter to be used rationally and neutrally or as if it were a "resource" provided by nature. My worry is that environmental anthropology in the guise of political ecology-in its rush to show how external structures affect local socioecological lives-has begun to translate local environmental understandings and actions in ways that generify them and that fail to show them to be aesthetic, poetic, and deeply social. Thus, political ecology is in danger of falling into the same trap as BCN did-failing to understand and demonstrate the nuances of how people come to know, produce, and be a part of environments, and missing aesthetic practices that may well be important political claims with material consequences. ${ }^{10}$

With regard to space, Harvey (1996) and Smith (1990) have both formulated productions of space as processes that draw space, place, time, and environment into dialectics to challenge how Cartesian-Kantian thinking limits our understandings of both contemporary social life and alternative futures (Harvey 1996:267; Smith 1990:25-33). Taking the example of the Gimi, this formulation can be expanded to include a discussion of how uniquely constituted persons bring their ideas and actions into spatial productions. It is neither simply that Gimi and their others produce incommensurable spaces nor that it is difficult to translate from one to another-how they know these spaces is also a problem of translation. Gimi know space through hunting, work, living, singing, and the like, whereas conservationists know space through investigation, questioning, reading, and the like. This is connected to issues of value. It is not that Gimi value forests, plants, and animals in different ways from outsiders-they do not necessarily "value" them at all, because Gimi do not separate themselves from their environment. As Gillison has shown, the Gimi have no notion of "nature" and no notion of "culture," only the transactive interactions between people and forests (Gillison 1980). To discuss how Gimi value their forests is to misunderstand Gimi ideas specifically as well as indigenous epistemology-a group's way of 
theorizing knowledge (Gegeo and Watson-Gegeo 2001:55)—generally.

For Gimi, the origin of knowledge is experience and cosmology, and one way they express it is through song. For the scientists associated with $\mathrm{BCN}$, the origin of knowledge is scientific examination, which is both generalizeable and replicable. For BCN economists, the origin of knowledge is the human's rational capability, which, if provided with perfect information, would function in the same model as the free market. BCN worked to try and fit Gimi belief, knowledge, and action into scientific and economic models by implementing projects that assumed that Gimi belief, knowledge, and action could be translated into Western categories. When something did not fit, it was treated as either a threat or an externality (Carrier and Miller 1998).

The actor-centered approach in political ecology suggests a vision of socioecological lives in which actors act on environments and on each other, and are likewise acted on. Even when the cosmological or supernatural is taken into account, it is often in terms of people fearing consequences that may have ecological implications. Political ecology often fails to make clear that all actors are composites. They are made up of relations with others; they do not simply act on environments and others but, rather, they act with environments and others, creating themselves, others, and environments in a series of dialectics (Walsh 2002). Relations are always reciprocal in some sense. Some political ecology also fails to take into account indigenous epistemologies and the fact that "how knowledge is theorized and constructed, encoded, and passed on to the next generation" (Gegeo and Watson-Gegeo 2001:57) should be one of the central foci of engaged environmental anthropology.

Cultural anthropology has already considered the problems that arise from ethnographies that merely translate local practice and knowledge into anthropological idioms instead of attempting to understand local practices and knowledges on their own terms. When biologists and others visit the Gimi, they expect to have local practices and knowledges translated for them, rather than learning the local idioms themselves. To put it another way, they interact on their own terms and in their own terms, rather than attempting to learn the local vernacular. As environmental anthropologists, we have to think carefully about how we translate socioecological lives, and we need to locate the politics of translation, value, and spatial production at the heart of an engaged environmental anthropology.

PAIGe West Department of Anthropology, Barnard College, Columbia University, New York, NY 10027

\section{NOTES}

Acknowledgments. I wish to acknowledge funding from Barnard College and the Wenner-Gren Foundation; the assistance of Phillip Ine, Ellen Tom, and the residents of Maimafu Village; and logistical support from the Research and Conservation Foundation and the Wildlife Conservation Society. James G. Carrier, Danielle DiNovelli-
Lang, Peter Dwyer, Nadia Abu El-Haj, Jamon Halvaksz, Robin Hide, Susan Lees, Lynn Meskell, Paul Roscoe, Nan Rothschild, J. C. Salyer, Bambi Schieffelin, Mayumi Shimose, and Andrew Walsh provided useful comments on drafts of this article.

1. This is not to say that the mountain called "Crater Mountain" is not a real place but, rather, that it has become "Crater Mountain" through a particular social and political history.

2. There is a large literature on hunting in PNG. For an analysis of wildlife exploitation to the southwest of Maimafu, see Hide 1984. For debates about hunting and gathering, see Dwyer and Minnegal 1991 and Roscoe 1990, 2002. For examinations of energetics, see Dwyer 1983, 1985 and Morren 1977, 1986. For data on classification, see Morren 1989 and Sillitoe 2002. Sillitoe (2001) has also written about the conservation-related aspects of conservation.

3. See West 2000 and Ellis 2002 for the history of the ICDP at Crater Mountain, and Van Helden 1998, 2001 and Wagner 2002, 2003 for other analyses of other ICDPs in PNG.

4. In the past, the ritual consumption of men's bodies by women and children was an important part of this process (Gillison 1993).

5. For analyses of gender relations among Gimi, see Gillison 1993, Strathern 1988, and West in press.

6. Leach (2003:195) makes a similar argument about Reite villagers in PNG.

7. Sorcery has made a good match with the market system, which is rapidly becoming the medium for exchange in Maimafu. Men who understand and practice divination rituals charge cash for their services, as do men and women who practice sorcery.

8. Stasch (1996) shows that for the Kiwai of New Guinea, hunting was symbolically tied to human reproduction and morality.

9. Gillison's work, which I have cited extensively, is deeply nuanced rich ethnography, yet BCN choose not to use it.

10. In anthropology, there are some exceptions to this: see, for example, Biersack 1999, Brosius 1999, Hayden 2003, Jacka 2003, Raffles 2002, and Slater 2002.

\section{REFERENCES CITED}

Berlin, Brent

1992 Ethnobiological Classification: Principles of Categorization of Plants and Animals in Traditional Societies. Princeton: Princeton University Press.

Biersack, Aletta

1999 The Mount Kare Python and His Gold: Totemism and Ecology in the Papua New Guinea Highlands. American Anthropologist 101(1):68-87.

Biodiversity Support Program (BSP)

1996 Biodiversity Conservation Network 1996 Annual Report: Stories from the Field and Lessons Learned. Washington, DC: BSP.

Brosius, J. Peter

1999 Green Dots, Pink Hearts: Displacing Politics from the Malaysian Rain Forest. American Anthropologist 101(1):36-57.

Bulmer, R. N. H., and James Menzies

1972 Karam Classification of Marsupials and Rodents, Part One. Journal of the Polynesian Society 81:472-497.

Carrier, James G., and Daniel Miller

1998 Virtualism: A New Political Economy. Oxford: Berg.

Comaroff, Jean, and John Comaroff

1991 Of Revelation and Revolution: Christianity, Colonialism, and Consciousness in South Africa, vol. 1. Chicago: University of Chicago Press.

Dumbacher, Jack P., Bruce M. Beehler, T. F. Spande, H. M. Garraffo, and John W. Daly

1992 Homobatrachotoxin in Genus Pitohui: Chemical Defense in Birds? Science 258(4):799-801.

Dwyer, Peter D.

- 1983 Etolo Hunting Performance and Energetics. Human Ecology 11(2):145-174.

1985 A Hunt in New Guinea: Some Difficulties for Optimal Foraging Theory. Journal of Anthropological Research 20:243253. 
Dwyer, Peter D., and Monica Minnegal

1991 Hunting in Lowland, Tropical Rain Forest: Towards a Model of Non-Agricultural Subsistence. Human Ecology 19(2):187-212.

Edelman, Marc, and Angelique Haugerud

2005 Introduction: The Anthropology of Development and Globalization: From Classical Political Economy to Contemporary Neoliberalism. In The Anthropology of Development and Globalization. Marc Edelman and Angelique Haugerud, eds. Pp. 1-74. London: Blackwell.

Ellis, David M.

2002 Between Custom and Biodiversity: Local Histories and Market-Based Conservation in the Pio-Tura Region of Papua New Guinea. Ph.D. dissertation, Department of Anthropology, University of Kent at Canterbury.

Ellis, David M., and Paige West

2004 Local History as "Indigenous Knowledge": Aeroplanes, Conservation and Development in Haia and Maimafu, Papua New Guinea. In Investigating Local Knowledge: New Directions, New Approaches. A. Bicker, P. Sillitoe, and J. Pottier, eds. Pp. 105-127. London: Ashgate.

Errington, Frederick, and Deborah Gewertz

1995 Articulating Change in the "Last Unknown." Boulder, CO: Westview Press.

2001 On the Generification of Culture: From Blow Fish to Melanesian. Journal of the Royal Anthropological Institute (n.s.) 7(September):509-525.

Feld, Steven

1996 Waterfalls of Song: An Acoustemology of Place Resounding in Bosavi, Papua New Guinea. In Senses of Place. Steven Feld and Keith H. Basso, eds. Pp. 91-135. Santa Fe: School of American Research Press.

Gadgil, Michael

1993 Indigenous Knowledge for Biodiversity Conservation. Ambio 22(2-3):156.

-Gegeo, David Welchman, and Karen Ann Watson-Gegeo

2001 "How We Know": Kwara'ae Rural Villages Doing Indigenous Epistemology. The Contemporary Pacific 13(1):55-88.

Gillison, Gillian

1977 Fertility Rites and Sorcery in a New Guinea Village. National Geographic Magazine (July) 152(1):124-146.

1980 Images of Nature in Gimi Thought. In Nature, Culture and Gender. Carol MacCormack and Marilyn Strathern, eds. Pp. 143-173. Cambridge: Cambridge University Press.

1983a Cannibalism among Women in the Eastern Highlands of Papua New Guinea. In The Ethnography of Cannibalism. Paula Brown and Donald Tuzin, eds. Pp. 33-50. Washington, DC: Society for Psychological Anthropology.

1983b Living Theatre in New Guinea's Highlands. National Geographic Magazine (August) 164(2):147-169.

1987 Incest and the Atom of Kinship: The Role of the Mother's Brother in a New Guinea Highlands Society. Ethos 15(2):166202.

1991 The Flute Myth and the Law of Equivalence: Origins of a Principle of Exchange. In Big and Great Men: Personifications of Power in Melanesia. Maurice Godelier and Marilyn Strathern, eds. Pp. 174-196. Cambridge: Cambridge University Press.

1993 Between Culture and Fantasy: A New Guinea Highlands Mythology. Chicago: University of Chicago Press.

1994 Symbolic Homosexuality and Cultural Theory: The Unconscious Meaning of Sister Exchange among the Gimi of Highlands New Guinea. In Anthropology and Psychoanalysis: An Encounter through Culture. Suzette Heald and Ariane Deluz, eds. Pp. 210-224. London: Routledge.

Glick, Leonard B.

1963 Foundations of a Primitive Medical System: The Gimi of the New Guinea Highlands. Ph.D. dissertation, Graduate School of Arts and Sciences, University of Pennsylvania.

1964 Categories and Relations in Gimi Natural Science. American Anthropologist 66(suppl. 2):273-280.

1967 The Role of Choice in Gimi Kinship. Southwestern Journal of Anthropology 23:371-382.

1972 Musical Instruments in Ritual. In Encyclopaedia of Papua New Guinea. Melbourne: Melbourne University Press.
Harper, Janice

2002 Endangered Species: Health, Illness and Death among Madagascar's People of the Forest. Durham, NC: Carolina Academic Press.

Hartwick, Elaine, and Richard Peet

2003 Neoliberalism and Nature: The Case of the WTO. Annals of the American Academy (AAPSS) 590:188-203.

Harvey, David

1989 The Condition of Postmodernity: An Inquiry into the Origins of Cultural Change. Cambridge: Blackwell.

1996 Justice, Nature and the Geography of Difference. Cambridge: Blackwell.

Hayden, Cori

2003 When Nature Goes Public: The Making and Unmaking of Bioprospecting in Mexico. Princeton: Princeton University Press.

Hide, R. L., ed.

1984 South Simbu: Studies in Demography, Nutrition and Subsistence. The Research Report of the Simbu Land Use Project, vol. 6. Boroko, PNG: Institute of Applied Social and Economic Research.

Ingold, Tim

2000 The Perception of the Environment: Essays on Livelihood, Dwelling and Skill. New York: Routledge.

Jacka, Jerry K.

2003 God, Gold, and the Ground: Place-Based Political Ecology in a New Guinea Borderland. Ph.D. dissertation, Department of Anthropology, University of Oregon.

Johnson, Arlyne

1997 Processes for Effecting Community Participation in the Establishment of Protected Areas: A Case Study of the Crater Mountain Wildlife Management Area. In The Political Economy of Forest Management in Papua New Guinea Monograph, 32. Colin Filer, ed. Pp. 391-428. Boroko, PNG: National Research Institute.

Leach, James

2003 Creative Land: Place and Procreation on the Rai Coast of Papua New Guinea. London: Berg.

Lefebvre, Henri

1991 The Production of Space. Oxford: Oxford University Press.

Mack, A. L., and D. D. Wright

1996 Notes on the Occurrence and Feeding of Birds at Crater Mountain Biological Research Station, Papua New Guinea. Emu 96:89-101.

Morren, George E. B., Jr.

1977 From Hunting to Herding: Pigs and the Control of Energy in Montane New Guinea. In Subsistence and Survival: Rural Ecology in the Pacific. Tim Bayliss-Smith and Richard G. Feachem, ed. Pp. 273-315. London: Academic Press.

1986 The Miyanmin: Human Ecology of a Papua New Guinea Society. UMI Studies in Cultural Anthropology, 9. Ann Arbor: UMI Research Press.

1989 Mammals of the East Miyanmin Area, Telefomin District, Papua New Guinea, with Notes on Folk Knowledge and Taxonomy. Science in New Guinea 13(3):119-135.

Paulson, Susan, Lisa L. Gezon, and Michael Watts

2003 Locating the Political in Political Ecology: An Introduction. Human Organization 62(3):205-217.

Posey, D. A.

1998 The "Balance Sheet" and the "Sacred Balance": Valuing the Knowledge of Indigenous and Traditional Peoples. Worldviews: Environment, Culture, Religion 2:91-106.

Raffles, Hugh

2002 In Amazonia: A Natural History. Princeton: Princeton University Press.

Rappaport, Roy A.

1984 Pigs for the Ancestors: Ritual in the Ecology of a New Guinea People. New Haven, CT: Yale University Press.

Rea, Amadeo M.

1998 Folk Mammalogy of the Northern Pimans. Tucson: University of Arizona Press.

Research and Conservation Foundation of Papua New GuineaWildlife Conservation Society (RCF-WCS)

1995 Crater Mountain Wildlife Management Area: A Model for Testing the Linkage of Community-Based Enterprises with Conservation of Biodiversity. Unpublished grant proposal. 
Robbins, Joel

2003 Properties of Nature, Properties of Culture: Possession, Recognition, and the Substance of Politics in a Papua New Guinea Society. Suomen Anthropologi 1(28):9-28.

2004 Becoming Sinners: Christianity and Moral Torment in a Papua New Guinea Society. Berkeley: University of California Press.

Roscoe, Paul B.

1990 The Bow and Spreadnet: Ecological Origins of Hunting Technology. American Anthropologist 92(3):691-701.

2002 The Hunters and Gatherers of New Guinea. Current Anthropology 43(1):153-271.

Sachs, Wolfgang, ed.

1993 Global Ecology: A New Arena of Political Conflict. London: Zed Press.

Salafsky, Nick, and Eva Wollenberg

2000 Linking Livelihoods and Conservation: A Conceptual Framework and Scale for Assessing the Integration of Human Needs and Biodiversity. World Development 28(8):1421-1438.

Salafsky, Nick, H. Cauley, G. Balachander, B. Cordes, J. Parks, C. Margoluis, S. Bhatt, C. Encarnacion, D. Russell, and R. Margoluis

2001 A Systematic Test of an Enterprise Strategy for CommunityBased Biodiversity Conservation. Conservation Biology 15(6):1585-1595.

Schroeder, Richard

1995 Contradictions along the Commodity Road to Environmental Stabilization: Foresting Gambian Gardens. Antipode 27(4):325-342.

Scott, James C.

1998 Seeing Like a State: How Certain Schemes to Improve the Human Condition Have Failed. New Haven, CT: Yale University Press.

Sillitoe, Paul

1998a The Development of Indigenous Knowledge: A New Applied Anthropology. Current Anthropology 39(2):223252.

1998b What, Know Natives? Local Knowledge in Development. Social Anthropology 6(2):203-220.

2001 Hunting for Conservation in the Papua New Guinea Highlands. Ethnos 66(3):365-393.

2002 Contested Knowledge, Contingent Classification: Animals in the Highland of Papua New Guinea. American Anthropologist 104(4):1162-1171.

2003 Managing Animals in New Guinea: Preying the Game in the Highlands. London: Routledge.

Slater, Candace

2002 Entangled Edens: Visions of the Amazon. Berkeley: University of California Press.

Smith, Neil

1990 Uneven Development: Nature, Capital and the Production of Space. Oxford: Basil Blackwell.

1996 The Production of Nature. In Future Natural. George Robertson and Melinda Marsh, eds. Pp. 35-54. London: Routledge.

Stasch, Rupert

1996 Killing as Reproductive Agency: Dugong, Pigs, and Humanity among the Kiwai, circa 1900. Anthropos 91:359379.

Strathern, Marilyn

1988 The Gender of the Gift. Berkeley: University of California Press.

Tsing, Anna

2003 Cultivating the Wild: Honey-Hunting and Forest Management in Southeast Kalimantan. In Culture and the Question of Rights: Forests, Coasts and Seas in Southeast Asia. Charles Zerner, ed. Pp. 24-55. Durham, NC: Duke University Press.

Van Helden, Flip

1998 Between Cash and Conviction: The Social Context of the Bismarck-Ramu Integrated Conservation and Development Project. NRI Monograph, 33. Port Moresby: National Research Institute and the United Nations Development Programme.

2001 Through the Thicket: Disentangling the Social Dynamics of an Integrated Conservation and Development Project on Mainland Papua New Guinea. Ph.D. dissertation, Department of Anthropology, Wageningen Universiteit, the Netherlands.

Vayda, Andrew P.

1996 Methods and Explanations in the Study of Human Actions and Their Environmental Effects. (A CIFOR-WWF Special Publication). Bogar: Center for International Forestry Research (CIFOR).

Vayda, Andrew P., and Bradley B. Walters

1999 Against Political Ecology. Human Ecology 27(1):167-179.

Wagner, John

2002 Commons in Transition: An Analysis of Social and Ecological Change in a Coastal Rainforest Environment in Rural Papua New Guinea. Ph.D. Dissertation, Department of Anthropology, McGill University.

2003 The Politics of Accountability: An Institutional Analysis of the Conservation Movement in Papua New Guinea. Social Analysis 45(2):78-93.

Walsh, Andrew

2002 Responsibility, Taboos and "The Freedom To Do Otherwise" in Ankarana, Northern Madagascar. Journal of the Royal Anthropological Institute 8(3):451-468.

2004 In the Wake of Things: Speculating in and about Sapphires in Northern Madagascar. American Anthropologist 106(2):225-237.

Weiner, James F.

1991 The Empty Place: Poetry, Space, and Being among the Foi of Papua New Guinea. Bloomington: Indiana University Press.

West, Paige

2000 The Practices, Ideologies, and Consequences of Conservation and Development in Papua New Guinea. Ph.D. Dissertation, Department of Anthropology, Rutgers University.

2001 Environmental Non-Governmental Organizations and the Nature of Ethnographic Inquiry. Social Analysis (November) 45(2):55-77.

In press Conservation Is Our Government Now: The Politics of Ecology in Papua New Guinea. Durham, NC: Duke University Press.

West, Paige, and James G. Carrier

2004 Ecotourism and Authenticity: Getting Away from It All? Current Anthropology 45(4):483-498.

White, Geoffrey

1991 Identity through History. Cambridge: Cambridge University Press.

Wright, Debra D.

N.d. Preliminary Report on the Crater Mountain Biological Surveys. Unpublished MS, Asia Program, Wildlife Conservation Society.

Wright, Debra D., Johann Heinrich Jessen, Peter B. Burk, and Hector Gomez de Silva Garza

-1997 Tree and Liana Enumeration and Diversity on a OneHectare Plot in Papua New Guinea. Biotropica 29:250-260.

Zerner, Charles

2003 Moving Translations: Poetics, Performance, and Property in Indonesia and Malaysia. In Culture and the Question of Rights: Forests, Coasts and Seas in Southeast Asia. Charles Zerner, ed. Pp. 1-23. Durham, NC: Duke University Press. 